\title{
Natural Disaster Mitigation at Ben Taub Hospital
}

\author{
Jamion Lewis ${ }^{1}$, Ryan Lunsford ${ }^{2}$ \\ ${ }^{1}$ DBA Student, University of the IncarnateWord, San Antonio, USA, jslewis1@student.uiwtx.edu \\ ${ }^{2}$ Professor of Business, University of the Incarnate Word, San Antonio, USA, lunsford@uiwtx.edu
}

\begin{abstract}
Ben Taub Hospital has garnered respect internationally as an exceptional acute care facility earning the Beacon Award for Excellence. Natural disasters impose substantial health burdens on affected populations and the capacity of healthcare facility capabilities. Natural disasters result in 68,000 deaths and affect 218,000,000 people worldwide annually. Ben Taub Hospital's preparedness level and disaster response efforts to Hurricane Harvey offer expertise resulting in best practices for healthcare organizations as they navigate the global disaster landscape.
\end{abstract}

KEYWORDS: Ben Taub, Emergency Management, Disaster Response, Hurricane Harvey

\section{Introduction}

The hurricane season of 2017 was the most costly in U.S. history, with estimates of damage north of $\$ 250$ billion. Three hurricanes in particular: Harvey, which hit southwest Texas, Irma, which hit Florida, and Maria, which devastated Puerto Rico wrought massive damage. Each of these three storms also brought unique emergency preparedness and disaster recovery challenges for facility managers (Zimmerman 2018). Preparing hospitals and healthcare facilities for disasters is a national level priority (Toner 2017). In this case study, the author will focus on a Ben Taub hospital's level of planning, specifically for patient evacuations before Hurricane Harvey.

\section{Problem}

The media claims that Ben Taub hospital treated storm victims initially, but their preparedness level for potential evacuation placed themselves and their patients at risk (Fink \& Blinder 2017). McGlown, O'Connor, \& Shewchuk (2017) make the claim that a basic problem in healthcare disaster planning is unfunded mandates. "The costs of planning are borne by specific institutions, but benefits are distributed widely across other organizations and the general public and may not be realized for years, or decades" (McGlown, O'Connor, \& Shewchuk 2017). The hospital's leadership should ensure that current and incoming patients are properly cared for as well as informing the public authorities about planning efforts the hospital have put into action. It is important for hospital leadership to also inform public authorizes what the facility cannot accomplish due to lack of funding or resources (McGlown, O'Connor, \& Shewchuk 2017). Ben Taub Hospital, who is a part of the Texas Medical Center that has spent billions on preparing for natural disasters such as Hurricane Harvey, was portrayed to be ill-prepared to evacuate its patients in a timely manner by multiple media authorities. This case study attempts to find a better understanding of why this financially prepared institution did not evacuate before the major flooding from Hurricane Harvey that left 350 patients at risk.

Ben Taub Hospital is a part of the healthcare network known as the Texas Medical Center and with 440 beds; Ben Taub is the largest hospital in the System. Ben Taub serves as a teaching hospital, and is one of only two, Level I trauma centers in the area (Patient Safety Monitor Journal 2018). The issue in responding to Hurricane Harvey was the flooding. "At one point, we didn't know if we were going to be able to save the hospital," says the Ben Taub Hospital Facilities Director (Patient Safety Monitor Journal 2018). Although over the last few years, Ben Taub Hospital's Emergency Operations Plan has been updated a multitude of times after storms, the facility was yet inundated by floodwaters for more than five days during Harvey (Patient Safety Monitor Journal 2018).

\section{Background}

Natural disasters are known to cause devastation to communities and their resources and an essential resource needed for any disaster is medical capability. The World Health Organization states that dozens of hospitals and health facilities each year are impacted by floods, hurricanes, cyclones, 
earthquakes, and other natural hazards because safety measures were not integrated into their design, location or construction (World Health Organization 2009). Some media authorities claimed that Ben Taub Hospital's staff and patients had consequently become victims themselves of the effects caused by natural disasters and the lack of preparation. "Water rose in the basement of Ben Taub Hospital, a major county trauma center in the vast Texas Medical Center campus that had spent billions of dollars on flood protections after being devastated in Tropical Storm Allison in 2001" (Fink \& Blinder 2017). Hospital officials announced they were evacuating, but hours later, a hospital spokesman said it had not yet begun because the hospital was surrounded by water and rescuers could not reach its 350 patients (Fink \& Blinder 2017). The next afternoon, a call went out on local radio for a vendor to provide food for the Ben Taub hospital (Fink \& Blinder 2017).

\section{Description}

The response to Hurricane Harvey wreaked havoc over the state of Texas a created a medically vulnerable in regard to whether Ben Taub Hospital did enough to prepare for the disaster and its ability to move their patients out of Harvey's path. Water poured into Houston hospitals, ambulances were caught in roiling floodwaters, and medical transport helicopters were grounded by high winds. In this disaster, Houston's world-renowned healthcare infrastructure found itself struggling to treat storm victims while becoming a victim itself. "Officials announced an evacuation Sunday, but hours later, a hospital spokesman said it had not yet begun because the hospital was surrounded by water and rescuers could not reach its 350 patients" (Fink \& Blinder 2017). After the extreme flooding brought on by Hurricane Katrina in 2005, dozens of hospital and nursing home patients died, and doctors awaiting rescue at one stranded and powerless hospital became so desperate, they intentionally hastened the deaths of their patients (Fink \& Blinder 2017). The Texas Department of State Health Services (DSHS) reported that Hurricane Harvey had caused 82 deaths in Texas as of August 2017 with property damage that could total $\$ 180$ billion (Morris, Miner, Rodriguez, Stancil, WiltzBeckham \& Chorba 2017). Houston alone received 45 inches of rain from August 24 to September 1, 2017, with flooding that forced 39,000 people from their homes and shelters (Morris, Miner, Rodriguez, Stancil, Wiltz-Beckham \& Chorba 2017). Houston's metro area has a patient population of 6.6 million residents and Hurricane Harvey affected 13 million people across 5 states (Amadeo, 2018).

\section{Hospital Evacuation Decision Guide}

When faced with a potential/evolving threat to patient and staff safety, hospital leadership must consider whether to evacuate. Per the U.S. Department of Health and Human Services Agency for Healthcare Research and Quality (2018), this decision has two possible outcomes: wait and reassess or start evacuation as the hospital may choose to wait and reassess if there is not a compelling reason to evacuate. The decision should be deferred and reconsidered at a later point, at which time the situation could significantly improve (i.e., no threat to patient/staff safety), significantly worsen (i.e., immediate threat to patient/staff safety), or not change significantly and require further careful assessment (Agency for Healthcare Research and Quality, 2018). Notable mentions are the Three Mile Island incident that took place in Pennsylvania, the Northridge earthquake that took place in California, and Hurricane Katrina that happened in Louisiana as all three of these disasters included decision teams that deferred the evacuation decision for a lengthy period of time (Agency for Healthcare Research and Quality, 2018). For starting the evacuation, the factors that should be considered in the pre-event evacuation decision are the same for post-event evacuations (Agency for Healthcare Research and Quality, 2018). "Actual post-event evacuations are often delayed as long as possible and are sometimes unavoidable due to loss of critical resources (Agency for Healthcare Research and Quality, 2018). 
Table 1. Pre-Event Evacuation Considerations

\begin{tabular}{|c|c|c|}
\hline Factor & Issues to Consider & Implications \\
\hline \multicolumn{3}{|c|}{ Event Characteristics } \\
\hline Arrival & $\begin{array}{l}\text { When is the event expected to } \\
\text { "hit" the hospital? The } \\
\text { metropolitan area? } \\
\text { How variable is the time the } \\
\text { event is expected to "hit"? }\end{array}$ & $\begin{array}{l}\text { The amount of time until the event } \\
\text { "hits," combined with the anticipated } \\
\text { time to evacuate patients, determines } \\
\text { how long an evacuation decision can be } \\
\text { deferred. }\end{array}$ \\
\hline Magnitude & $\begin{array}{l}\text { What is the expected strength } \\
\text { of the event? } \\
\text { How likely is the event to gain } \\
\text { or lose strength before it } \\
\text { reaches the hospital? The } \\
\text { metropolitan area? }\end{array}$ & $\begin{array}{l}\text { The magnitude of the event forewarns } \\
\text { the potential damage to a facility and } \\
\text { utilities, which could cut off the supply of } \\
\text { key resources, or otherwise limit the } \\
\text { ability to shelter-in-place and care for } \\
\text { patients. }\end{array}$ \\
\hline Area impacted & $\begin{array}{l}\text { How large is the geographic } \\
\text { area to be affected by the } \\
\text { event? } \\
\text { How many vulnerable health } \\
\text { care facilities are in this } \\
\text { geographic area? }\end{array}$ & $\begin{array}{l}\text { Competition for resources needed to } \\
\text { evacuate patients (especially vehicles) } \\
\text { increases when more facilities evacuate } \\
\text { simultaneously. }\end{array}$ \\
\hline Duration & $\begin{array}{l}\text { How long is the event expected } \\
\text { to last? } \\
\text { How variable is the expected } \\
\text { duration of the event? }\end{array}$ & $\begin{array}{l}\text { The duration of the event will affect how } \\
\text { long hospitals have to shelter-in-place } \\
\text { or operate on backup, alternative, or } \\
\text { less predictable sources of key } \\
\text { resources. }\end{array}$ \\
\hline \multicolumn{3}{|c|}{ Anticipated Effect of the Event on Key Resources Needed to Care for Patients } \\
\hline Water source & $\begin{array}{l}\text { Is the main city water supply in } \\
\text { jeopardy? Already non- } \\
\text { functional? } \\
\text { Is there a backup water supply } \\
\text { (well, nearby building with intact } \\
\text { water mains)? } \\
\text { If not, how soon will city water } \\
\text { return? }\end{array}$ & $\begin{array}{l}\text { Water loss of unknown duration (more } \\
\text { than } 1-2 \text { days) is almost always cause } \\
\text { for evacuation. }\end{array}$ \\
\hline Heat source & $\begin{array}{l}\text { Is the heat source in jeopardy } \\
\text { (steam, water for boilers, etc.)? } \\
\text { Already non-functional? } \\
\text { Is there a backup (intact nearby } \\
\text { building that still has }\end{array}$ & $\begin{array}{l}\text { Loss of heat, especially during a } \\
\text { northern winter, is almost always a } \\
\text { cause for evacuation-often within } 12 \\
\text { hours. }\end{array}$ \\
\hline
\end{tabular}




\begin{tabular}{|c|c|c|}
\hline & $\begin{array}{l}\text { power/heat)? } \\
\text { If not, will the building be too } \\
\text { cold for patient safety before } \\
\text { adequate heat returns? }\end{array}$ & \\
\hline Electricity & $\begin{array}{l}\text { Is power in jeopardy? Just for } \\
\text { the hospital or a wider area? } \\
\text { Are backup generators } \\
\text { functional? How long can they } \\
\text { run without refueling? Is } \\
\text { refueling possible (e.g., intake } \\
\text { not under water)? } \\
\text { Can some sections/wings be } \\
\text { shut down to reduce fuel } \\
\text { consumption and stretch fuel } \\
\text { supplies? }\end{array}$ & $\begin{array}{l}\text { Loss of electricity endangers ventilated } \\
\text { patients, among others, and may affect } \\
\text { the sequence in which patients are } \\
\text { evacuated. }\end{array}$ \\
\hline $\begin{array}{l}\text { Building structural } \\
\text { integrity }\end{array}$ & $\begin{array}{l}\text { Is the building obviously/visibly } \\
\text { unsafe? All of it or only portions } \\
\text { (e.g., can people be } \\
\text { consolidated in safer sections)? } \\
\text { Was there a water tower on the } \\
\text { roof, and is it intact? } \\
\text { Is a building engineer needed } \\
\text { to determine structural } \\
\text { integrity/safety? }\end{array}$ & $\begin{array}{l}\text { Earthquakes or explosions may cause } \\
\text { rooftop water towers to fail, flooding the } \\
\text { building. } \\
\text { Safety/integrity may not be obvious to } \\
\text { untrained occupants. }\end{array}$ \\
\hline \multicolumn{3}{|c|}{$\begin{array}{l}\text { Anticipated Effect of the Event on the Surrounding Environment and Community That Could } \\
\text { Affect an Evacuation Decision }\end{array}$} \\
\hline Road conditions & $\begin{array}{l}\text { Are any major routes from the } \\
\text { hospital to potential receiving } \\
\text { care sites closed? } \\
\text { Is traffic at gridlock on major } \\
\text { routes from the hospital to } \\
\text { potential receiving care sites? } \\
\text { Are access routes to the } \\
\text { hospital cut off? }\end{array}$ & $\begin{array}{l}\text { There may be a limited window of } \\
\text { opportunity to carry out a ground-based } \\
\text { evacuation. } \\
\text { Increased use of helicopters to } \\
\text { evacuate patients may be required. } \\
\text { Staff may not be able to get to the } \\
\text { hospital to relieve existing staff or assist } \\
\text { in the evacuation. }\end{array}$ \\
\hline $\begin{array}{l}\text { Community/building } \\
\text { security }\end{array}$ & $\begin{array}{l}\text { Have any nearby areas } \\
\text { experienced increases in } \\
\text { disorder or looting? } \\
\text { Are local law enforcement } \\
\text { agencies understaffed due to } \\
\text { self-evacuations or significant } \\
\text { additional responsibilities? } \\
\text { Are additional private security } \\
\text { officers available to secure the } \\
\text { hospital? }\end{array}$ & $\begin{array}{l}\text { If patient and staff safety cannot be } \\
\text { assured, evacuation will be necessary. }\end{array}$ \\
\hline
\end{tabular}




\begin{tabular}{|c|c|c|}
\hline $\begin{array}{l}\text { Evacuation status of } \\
\text { other nearby health } \\
\text { care facilities }\end{array}$ & $\begin{array}{l}\text { Are other hospitals or other } \\
\text { health care facilities already } \\
\text { evacuating or planning to } \\
\text { evacuate, or have they decided } \\
\text { to shelter-in-place? }\end{array}$ & $\begin{array}{l}\text { If other hospitals or health care facilities } \\
\text { are evacuating: } \\
\text { the competition for ambulances, } \\
\text { wheelchair vans, and buses may be } \\
\text { substantially increased. } \\
\text { the hospital may be asked to accept } \\
\text { additional patients. } \\
\text { patients may have to be relocated to } \\
\text { facilities further away than anticipated. }\end{array}$ \\
\hline $\begin{array}{l}\text { State/county/local } \\
\text { evacuation order }\end{array}$ & $\begin{array}{l}\text { Have evacuation orders been } \\
\text { issued in areas that are closer } \\
\text { to the event? } \\
\text { Have any public or private } \\
\text { statements been issued } \\
\text { regarding the possibility of an } \\
\text { evacuation order? } \\
\text { Have any other incidents } \\
\text { occurred that increase the } \\
\text { likelihood that an evacuation } \\
\text { order will be issued? }\end{array}$ & $\begin{array}{l}\text { You may have no choice but to } \\
\text { evacuate. }\end{array}$ \\
\hline $\begin{array}{l}\text { Availability of local } \\
\text { emergency response } \\
\text { agencies }\end{array}$ & $\begin{array}{l}\text { Are local emergency response } \\
\text { agencies understaffed (or } \\
\text { otherwise unavailable) due to } \\
\text { self-evacuations or additional } \\
\text { responsibilities? }\end{array}$ & $\begin{array}{l}\text { Unavailability of local fire agencies } \\
\text { increases the risk of sheltering-in-place. }\end{array}$ \\
\hline
\end{tabular}

Note. Agency for Healthcare Research and Quality (2018).

Some of the possible paths are determining the following:

a) There is an immediate threat to patients and ordering an immediate post-event evacuation.

b) Monitoring a potential/evolving threat to patient safety during a wait-and-reassess period, and then ultimately not evacuating the hospital.

c) Monitoring a potential/evolving threat to patient safety during a wait-and-reassess period, and then deciding to evacuate the hospital. (Agency for Healthcare Research and Quality, 2018)

The flowchart below describes the decision process for an Advanced Warning Event like Hurricane Harvey. 


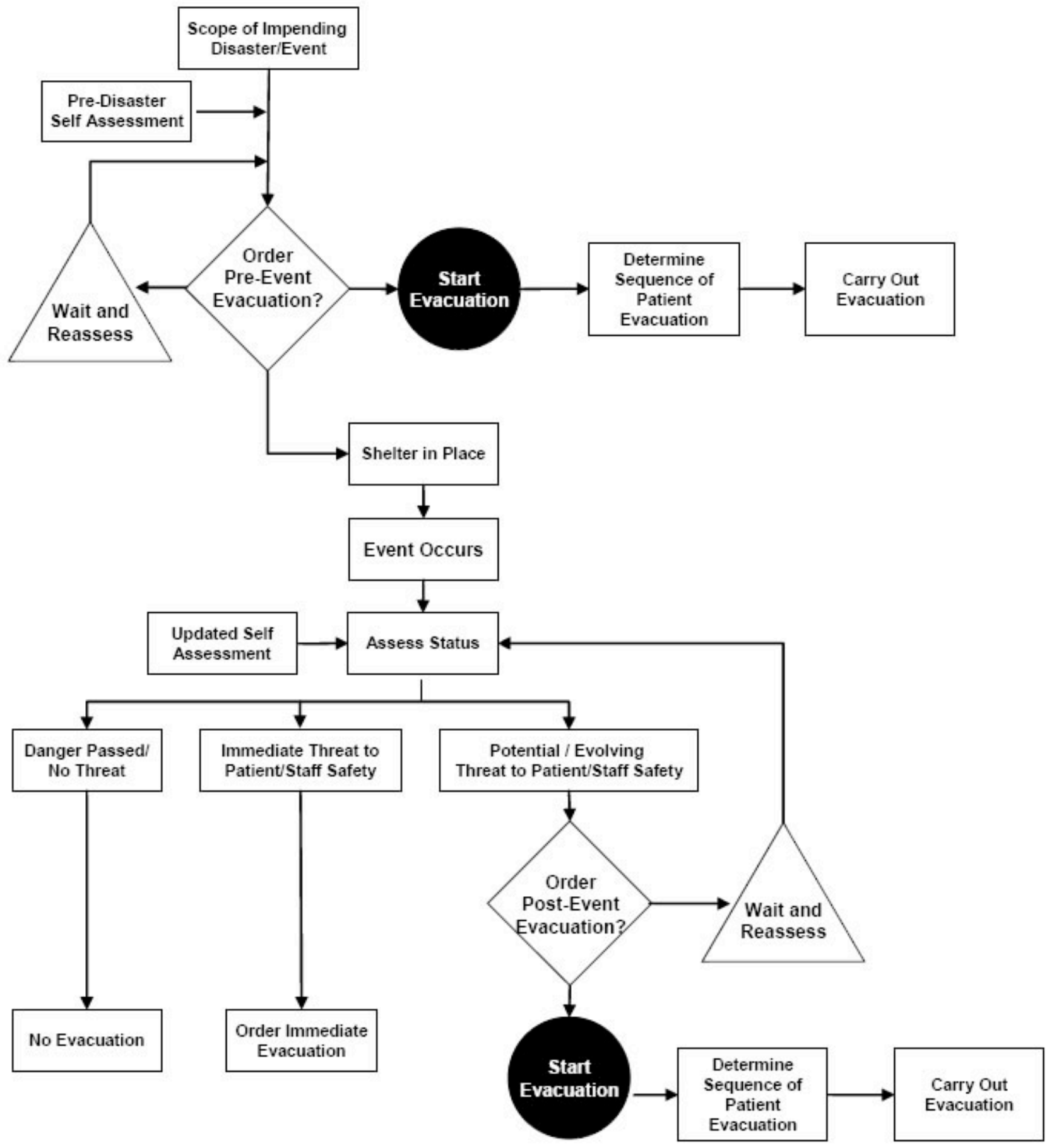

Figure 1. Flowchart for an Advanced Warning Event. Reprinted from Agency for Healthcare Research and Quality, 2018, Hospital Evacuation Decision Guide. Retrieved from: https://www.ahrq.gov/research/shuttered/hospevac4.html

\section{Healthcare Preparedness}

Disasters are diverse events such as storms, droughts, wildfires, floods, earthquakes, chemical and industrial accidents, burns, mass shootings and bombings, and epidemics occur nearly every day in the United States, and the frequency is increasing (Toner 2017). Sickened or injured people require a wellprepared healthcare system and the number of people killed by disasters depends not only on the severity of the event itself but also on our ability to respond effectively and treat the ill or injured (Toner 2017). Whether it is a natural disaster like an earthquake and hurricane or a manmade disaster like terrorism, healthcare preparedness reduces risk (Toner 2017). 
Risk $=$ Threat $\times$ Vulnerability $\times$ Consequence; therefore, even if we are not successful in reducing the threat of disasters or our vulnerability to them, we can reduce our nation's risk by mitigating the consequences - by preparing health facilities to treat the sick (Toner 2017). Healthcare preparedness is focused on saving lives and reducing the long-term health consequences of disasters (Toner 2017).

\section{Unexpected Issues}

Ben Taub leadership stated that as Harvey approached, everyone knew their jobs and that emergency systems were checked and supplies were bolstered, including sandbags (Patient Safety Monitor Journal, 2018). Ben Taub maintains a supply of sandbags as standard procedure, but extra pallets were brought in before the storm as a precaution. The hospital had a pipe burst in the basement of the facility, which caused contamination of the hospital's food supply, the closure of its pharmacy, and damaged medical supplies (Deam 2017). At that point, Ben Taub called to evacuate their nearly 350 patients; this captured national news, and it was noted that evacuations were slow (Deam 2017). There were three documented attempts of unsuccessful critical patient relocations due to rising waters around the Texas Medical Center. You can expect to encounter wind and rain, and you expect leaks, and that is exactly what we got," says Ben Taub's facility manager. He also stated that the facility got leaks from places he never thought possible (Zimmerman 2018). As the storm raged from Hurricane Harvey, a 6-inch pipe suffered a 30-foot gash, unleashing a rush of stormwater into the facility's basement and if the team didn't stop this, they were going to lose the hospital (Zimmerman 2018).

\section{Preventing Evacuation}

The Agency for Healthcare Research and Quality (2018) assumes that hospitals will be in one of three conditions following the event: No threat to patient/staff safety, Immediate threat to patient/staff safety, or Potential/evolving threat to patient/staff safety. In regard of no threat to patient/staff safety, it is immediately clear that the hospital did not suffer any significant damage that would cause decision teams to order an evacuation (Agency for Healthcare Research and Quality, 2018). "This is the usual outcome for hospitals that experience minor earthquakes or that shelter-in-place throughout a hurricane and suffer little or no significant damage" (Agency for Healthcare Research and Quality, 2018). The immediate threat to patient/staff safety is at the other extreme in which the event clearly causes an immediate life-threatening risk to patients and staff, and the hospital must be rapidly evacuated (Agency for Healthcare Research and Quality, 2018). The potentially evolving threat to patient and staff safety is the situation that is between the two previous mentioned extremes when it is not immediately obvious whether or not the hospital should be evacuated (Agency for Healthcare Research and Quality, 2018). "Hurricane Katrina illustrated this situation; many decision teams chose to shelter-in-place, only to find that catastrophic damage from the subsequent flood necessitated evacuation" (Agency for Healthcare Research and Quality, 2018). A careful assessment of the risks posed to the hospital's water, sewer, electricity, and heat supply, as well as the overall building integrity is required in order to decide whether an evacuation should be ordered, or if the decision should be deferred and the situation reassessed (Agency for Healthcare Research and Quality, 2018). Ben Taub was faced with a similar situation as Hurricane Harvey was rapidly approaching.

Ben Taub's Facility Manager stated that the mood on his team was darkening rapidly as flooding began from a 6-inch pipe burst, but he lined up his team, gave them a pep talk, and the ideas started flowing (Zimmerman 2018). He called Houston's non-emergency 311 number and was amazed when he got a call back from a city official 15 minutes later offering to help with some pumps (Zimmerman 2018). The Ben Taub Facilities Team was in the process of making canals with sandbags down the hallways to direct water to drains and as soon as the pumps started, the staff could tell that the water was receding (Zimmerman 2018). The hospital wasn't out of danger yet as Ben Taub is located near a bayou and the pressure from the overflowing bayou on storm sewers caused another pipe in a different part of the facility to blow a cap (Zimmerman 2018). Shortly after the second burst, there were nearly six feet of water flooding into a mechanical room, coming dangerously close to swamping some vital electrical and telecommunications equipment; had this equipment been drenched, the hospital would have had to been evacuated (Zimmerman 2018). The 
Ben Taub Facilities Team quickly found a 2x6 board and used that as a temporary cap while one of the team members literally went swimming to find the blown-off cap (Zimmerman 2018). "Meanwhile, as they re-secured the pipe cap, other members of the team grabbed an electric concrete drill - fully aware of the hazard of using electricity around flooding water - to drill holes in a cinder block wall and "vent" the water" (Zimmerman 2018). The facility manager stated, "Our guys were all standing in a line, holding up the extension cord and we were just hoping no one dropped their part of the cord" (Zimmerman 2018). The facilities staff stopped the flooding before major equipment damage occurred. Their efforts were successful and soon the water started to recede and could be controlled more effectively; saving the sensitive electrical and telecommunications equipment and the possibility of evacuating the hospital was avoided (Zimmerman 2018).

\section{Recovery}

With the major issues under control, Ben Taub Facility Manager began thinking about recovery and noted that constant contact with disaster recovery and plumbing contractors was essential (Zimmerman, 2018). Having those two companies ready to get there as soon as the storm ended was a key takeaway for any facility hoping for business continuity (Zimmerman 2018). The facilities team used infrared moisture meters to identify leaks and other areas affected as well as began replacing drywall and sheetrock immediately and it took about three weeks for full recovery meaning that every patient room was back online and operations were back to fully normal" (Zimmerman 2018). The chief operating officer at Harris Health System in Houston, Dr. Ericka Brown, requested consideration in prepositioning emergency food and medical items closer to the hospital and to review the physical location of critical equipment and systems to ensure their continued operation in a natural disaster (Patient Safety Monitor Journal, 2018). She also noted the importance of making sure you take care of your staff after the storm (Patient Safety Monitor Journal, 2018). There were more than 400 employees from Harris Health System that had homes significantly damaged or destroyed in the flood caused by Harvey. Ben Taub Leadership, understanding that so many workers were impacted by the floodwaters, decided that response and recovery after the storm meant helping staff members as well (Patient Safety Monitor Journal, 2018).

\section{Lessons Learned}

Even as hurricane veterans, the Ben Taub Facilities Team learned some valuable lessons from this storm and they recommended having tools on hand to be able to direct water out of the building (Zimmerman, 2018). The facility manager recommended having a more robust staff with more trades on hand for the ride-out team, including plumbers and electricians to manage things like generators and transfer switches (Zimmerman, 2018). Ben Taub Leadership recognized awareness as a significant lesson learned as staff can be heroes and victims; therefore, the need of managing staff expectations for a five-day ride experience is critical to mitigating burnout and fatigue during and after the disaster (Patient Safety Monitor Journal, 2018). "One gap in the coordination of care surfaced with retail pharmacies, with many unable to maintain operations during and following the storm. A possible solution may include integrating continuity of operation planning and personnel resourcing between hospital facilities and pharmacy locations" (Phillips, Schwartz, McKeon \& Boom, 2017).

\section{Recommended Actions}

The Harris County Office of Homeland Security \& Emergency Management released its Hurricane Harvey After Action Report on 1 June 12018. This document reviews the county's overall response efforts and was developed with the input and collaboration of numerous local, state, federal, private and nonprofits organizations working at the Emergency Operations Center during the Harvey activation (Harris County Emergency Management, 2018). The Hurricane Harvey after action report provides an analysis of areas for improvement noting that some items can be fixed quickly, while others will require a major long-term investment of time and money (Harris County Emergency Management, 2018). The report identifies some primary areas for improvement that include: 
- Developing a countywide Continuity of Operations Plan

- Training nontraditional support personnel who may be involved in disaster response operations

- Transitioning from response to recovery operations in the Emergency Operations Center

- Working with the city of Houston to address the current Donations Management strategy. (Harris County Emergency Management, 2018)

\section{Conclusion}

Hurricane Harvey is the most destructive storm in U.S. history, causing an estimated $\$ 125$ billion of damage. The storm dumped about 50 inches of rain on the Houston area in seven days, more than the average annual rainfall for most U.S. cities. As a result, Houston experienced some of the worst urban flooding since New Orleans after Hurricane Katrina in 2005 (Zimmerman 2018). Nevertheless, despite major improvements to ensure continuity of operations, challenges remained during Harvey. "One challenge was a lack of advanced planning for dialysis patients, whose usual facilities became inoperable during and immediately following the storm" (Phillips, Schwartz, McKeon \& Boom 2017). Another challenge that was noted was in regard to social media. This form of communication was generally helpful such as postings about the availability of facilities; at times it rapidly propagated misinformation (Phillips, Schwartz, McKeon \& Boom 2017). "For example, social media reported that the Houston Methodist Hospital in the TMC had flooded, when in fact it remained operational throughout the storm; conversely, social media was utilized quickly to correct the misinformation." (Phillips, Schwartz, McKeon \& Boom 2017). In pursuing aspirations of becoming a high-reliability organization demands that health care facilities continue to learn from failures and embody a commitment to resiliency. Preparation, planning, and response of the Ben Taub Hospital and the subsequent outcome of Harvey are expressions of this commitment.

\section{References}

Agency for Healthcare Research and Quality. 2018. Hospital Evacuation Decision Guide. Retrieved from: https://www.ahrq.gov/research/shuttered/hospevac4.html.

Amadeo, K. 2018. "Hurricane Harvey Facts, Damage and Costs.' The Balance. Retrieved from: https://www.thebalance.com/hurricane-harvey-facts-damage-costs-4150087.

American Hospital Directory. 2018. "Identification and Characteristics: Ben Taub General Hospital." American Hospital Directory (AHD). Retrieved from: https://www.ahd.com/free_profile/450289/Ben_Taub_General_Hospital/ Houston/Texas/.

Business Day Markets. 2018. "Healthcare Facilities." The New York Times. Retrieved from: https://markets.on.nytimes.com/research/markets/usmarkets/industry.asp?industry=56121\&sector=56.

Deam, J. 2017. "Ben Taub Hospital abandons plans to evacuate patients." Chron. Retrieved from: https://www.chron.com/business/medical/article/Ben-Taub-abandons-plans-for-patient-evacuations-12159207.php.

Fink, S., \& Blinder, A. 2017. "Houston's Hospitals Treat Storm Victims and Become Victims Themselves." The New York Times. Retrieved from: https://www.nytimes.com/2017/08/28/us/hurricane-harvey-houston-hospitals-rescue.html.

Harris County Emergency Management. 2018. Hurricane Harvey After Action Report. Retrieved from: https://www.readyharris.org/Portals/43/PDFs/Hurricane\%20Harvery\%20AAR_Final.pdf?ver=2018-05-14-144548187.

Harris Health System. 2018. Awards and Distinctions. Retrieved from: https://www.harrishealth.org/about-ushh/Pages/awards-and-distinctions.aspx.

Harris Health System. 2018. Ben Taub Hospital. Retrieved from: https://www.harrishealth.org/locations-hh/Pages/bentaub.aspx.

McGlown, J., O'Connor, S., \& Shewchuk, R. 2017. Evidence-Based Criteria for Hospital Evacuation, Ten Years After Hurricane Katrina. Retrieved from: https://www.researchgate.net/publication/316110631_EvidenceBased_Criteria_for_Hospital_Evacuation_Ten_Years_After_Hurricane_Katrina.

Morris S, Miner M, Rodriguez T, Stancil R, Wiltz-Beckham D, Chorba T. 2017 . Notes from the Field: Tuberculosis Control Activities After Hurricane Harvey — Texas, 2017. MMWR Morb Mortal Wkly Rep 2017;66:1362-1363. DOI: http://dx.doi.org/10.15585/mmwr.mm6649a5.

National Academies Press. 2015. Evacuation, Patient Tracking, and Information Sharing in a Regional Response. Retrieved from: https://www.ncbi.nlm.nih.gov/books/NBK311256/.

Patient Safety Monitor Journal. 2018. Harris Health System vs. Hurricane Harvey. Retrieved from: https://www.psqh.com/analysis/harris-health-system-vs-hurricane-harvey/. 
Phillips, R., Schwartz, R., McKeon, W., \& Boom, M. 2017. “Lessons in Leadership: How the World's Largest Medical Center Braced for Hurricane Harvey.” NEJM Catalyst. Retrieved from: https://catalyst.nejm.org/lessons-leadershiptexas-medical-center-hurricane-harvey/.

Stojkavic, P. 2018. "Harris Health System: Ben Taub, Emergency Department Expansion." Retrieved from: Ihttps://transwestern.com/source/files/Case $\% 20$ Studies/Harris $\% 20 H e a l t h \% 20$ System $\% 20$ $\% 20$ Ben $\% 20$ Taub\%2C\%20Emergency\%20Dept\%20Expansion\%20I.pdf.

Toner, E. 2017. Healthcare Preparedness: Saving Lives. Health security 15(1): 8-11.

World Health Organization. 2009. Hospitals Must Be Protected During Natural Disasters. Retrieved from: http://www.who.int/mediacentre/news/releases/2009/disaster_day_20091014/en/.

Zimmerman, G. 2018. Hurricane Harvey: FM's Quick Thinking Saves Houston Hospital From Evacuation. Retrieved from: https://www.facilitiesnet.com/emergencypreparedness/article/Hurricane-Harvey-FMs-Quick-Thinking-SavesHouston-Hospital-From-Evacuation-Facilities-Management-Emergency-Preparedness-Feature--17661. 